\title{
Air Quality in East Asia during the heavy haze event period of 10 to 15 January 2013
}

\author{
Soon-Ung Park, Jeong Hoon Cho \\ Center for Atmospheric and Environmental Modeling \\ Seoul, Korea
}

Received: December 28, 2020. Revised: February 10, 2021. Accepted: March 3, 2021. Published: March $24,2021$.

\begin{abstract}
A prolonged heavy haze event that has caused for the Environmental Protection Bureau (EPB) in Beijing to take emergency measures for the protection of the public health and the reduction of air pollution damages in China has been analyzed with the use of the Aerosol modeling System (AMS) to identify causes of this event. It is found that the heavy haze event is associated with high aerosols and water droplets concentrations. These high aerosol concentrations are mainly composed of anthropogenic aerosols, especially secondary inorganic aerosols formed by gas-to-particle conversion of gaseous pollutants in the eastern part of China whereas those in the northeastern parts of China are composed of the mixture of the anthropogenic aerosols and the Asian dust aerosol originated from the dust source regions of northern China and Mongolia. These high aerosol concentrations are found to be subsequently transported to the downwind regions of the Korean Peninsula and Japan causing a prolonged haze event there. It is also found that the Asian dust aerosol originated from northern China and Mongolia and the anthropogenic aerosols produced by chemical reactions of pollutants in the high emissions region of eastern China can cause significantly adverse environmental impacts in the whole Asian region by increased atmospheric aerosol loadings that may cause respiration diseases and visibility reduction and by excess deposition of aerosols causing adverse impacts on terrestrial and marine eco-systems.
\end{abstract}

Keywords-Aerosol loading and deposition; Aerosol Modeling System (AMS); Anthropogenic aerosol; Asian Dust Aerosol Model 2 (ADAM2); CMAQ; Pollutants emissions in Asia

\section{INTRODUCTION}

Air quality is defined as a measure of the condition of air relative to the requirements of one or more biotic species and/or human need or purpose [1]. Poor air quality in East Asia has become a major environmental problem in recent years due to rapid economical growths in most of Asian countries. The air quality is largely determined by concentrations of gaseous pollutants $\left(\mathrm{SO}_{2}, \mathrm{NO}_{\mathrm{X}}, \mathrm{CO}, \mathrm{O}_{3}\right)$ and atmospheric aerosols [2][3][4][5].

Atmospheric aerosols can affect the quality of our lives significantly because of its potential impacts on human health and the environment. The submicrometer size of aerosols can be inhaled and thus may pose certain health hazards [6][7] $[8][9][10][11][12]$. Because aerosols also scatter light, they strongly influence the radiative budget of the Earth-atmosphere system; they also reduce visibility and diminish the aesthetic scenery $[13][14][15][16][17][18][19][20]$. Visibility reduction is usually caused by weather phenomena such as precipitation, fog, mist, haze and dust that are associated with hydrometeor and lithometeor [21].

East Asia is a major source of both natural aerosol (Asian dust) and anthropogenic aerosols over the Northern Hemisphere. Asian dust that is a typical example of mineral aerosol occurs in northern China and Mongolia more frequently during the spring season [22][23][24][25] and has its increasing occurrence trend due to desertification in the source region. Anthropogenic aerosols that are mainly originated from emitted pollutants have also an increasing trend due to the rapid economic expansion in many Asian countries [26][27]. Tropospheric aerosols in this region are the complex mixture of various aerosols such as Asian dust and anthropogenic aerosols. Consequently, occurrence frequencies of visibility reducing weather events caused by aerosols have an increasing trend, especially over Asia [28][29][30].

Visibility reducing weather phenomena caused by aerosols include precipitation, fog, mist, haze and dust storm [21]. Among these, mist and haze that are composed of submicrometer particles are mainly formed by gas-to-particle conversion processes in the atmosphere [31][32][33]. The recent increasing occurrence frequency of dense haze and mist events in the eastern parts of China appears to be related to this size range of secondary inorganic aerosols that are formed through the chemical reactions of gaseous pollutants such as $\mathrm{SO}_{2}, \mathrm{NO}_{\mathrm{X}}, \mathrm{NH}_{3}$ and water vapor.

In fact a wide swath of central and eastern China experienced several days of the worst air pollution the country has seen in recent memory, with the dense haze covering several provinces in China including Beijing, Hebei, Tianjing, Shandong, Henan, Jiangsu, Anhui, Jiangxi and Hubei from 11 to 16 January 2013. These events caused for the Environmental Protection Bureau (EPB) in Beijing to take emergency measures including halting outdoor activities for primary and middle school students, suspending construction of 28 construction sites, reducing emissions by $30 \%$ at 58 factories, and taking up to $30 \%$ of government vehicles off the road (China Daily). Haze (Smog) blanketed Shandong and Jiangxi provinces has forced the closure of many highways and the cancellation or delay of many air flights during these events period. These dense haze events have been transported 
downwind regions causing high aerosol concentrations of more than $200 \mu \mathrm{g} \mathrm{m}^{-3}$ over Korea and $50 \mu \mathrm{g} \mathrm{m}^{-3}$ in parts of Japan.

Recently [27] has developed the Aerosol Modeling System (AMS) that is composed of the Asian Dust Aerosol Model 2 (ADAM2) for the Asian dust aerosol modeling and the Community Multiscale Air Quality (CMAQ) model for the anthropogenic aerosol modeling [34]. AMS could successfully simulate a prolonged dense haze event occurred during the period of 19-22 May 2010 [35] in East Asia.

The Purpose of this study is examine the air quality in association with dense haze and mist events occurred for the period from 10 to 15 January 2013 in East Asia with the use of Aerosol Modeling System (AMS) and to investigate the effects of various aerosol species on these hazardous environmental events.

\section{MODEL DESCRIPTIONS}

\section{A. Meteorological model}

The meteorological model used in this study is the fifth generation mesoscale model of non-hydrostatic version (MM5; Pennsylvania State University / National Center for Atmospheric Research) defined in the $\mathrm{x}, \mathrm{y}$ and $\sigma$ coordinate [36][37]. The model domain (Fig. 1) has the horizontal resolution of $27 \times 27 \mathrm{~km}^{2}$ with 30 vertical layers in the Asian region.

The NCEP FNL operational global analysis data on $1.0 \times$ 1.0 degree grids are used for the initial and lateral boundary conditions for the model.
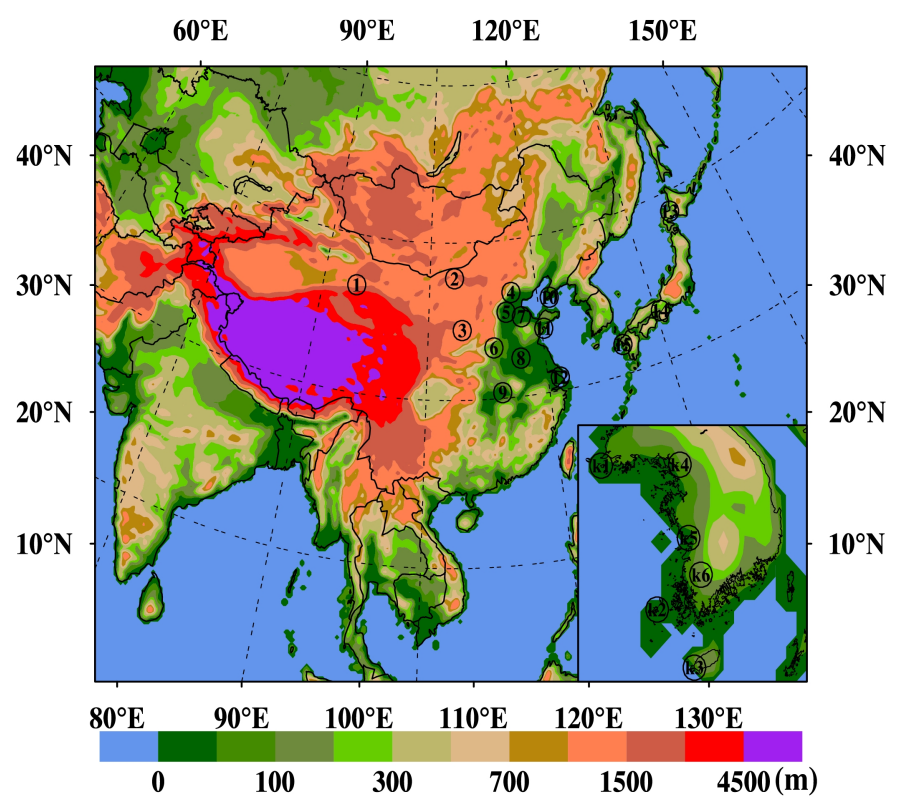

01 : Dunhuang / 02 : Wulatezhongqi / 03 : Yanan / 04 : Beijing / 05 : Baoding / 06 : Zhengzhou

07 : Huimin / 08 : Suzhou / 09 : Wuhan / 10 : Dalian / 11 : Qingdao / 12 : Shanghai

13 : Sapporo / 14 : Osaka / 15 : Nagasaki

k1 : Baengnyeongdo / k2 : Heuksando / k3 : Gosan / k4 : Seoul / k5 : Gunsan / k6 : Gwangju

Fig. 1. Topography of the model domain with the indication of sites that will be described in the text. The enhanced map of South Korea with the indication of monitoring sites is shown in the right lower corner of the

\section{B. Aerosol Modeling System (AMS)}

The Aerosol Modeling System (AMS) is consisted of the Asian Dust Aerosol Model 2 (ADAM2) [38] and the Community Multiscale Air Quality (CMAQ) modeling system (http://www.cmaq-model.org) with emission data of pollutants $\left(\mathrm{SO}_{2}, \mathrm{NO}_{\mathrm{X}}, \mathrm{VOC}, \mathrm{CO}, \mathrm{NH}_{3}, \mathrm{BC}, \mathrm{OC}\right.$ and $\left.\mathrm{PM}_{10}\right)$ in the model domain.

\section{1) $A D A M 2$}

The ADAM2 model is an Eulerian dust transport model that includes the specifications of the dust source regions delineated by the statistical analysis of the World Meteorological Organization (WMO) 3 hourly reporting dust data and statistically derived dust emission conditions in Sand, Gobi, Loess and Mixed surface soil in the model domain (Fig. 1). The model uses the suspended particle-size distribution parameterized by the several log-normal distributions in the source regions, based on the parent soil particle-size distributions with the used of the concept of the minimally and fully dispersed particle-size distribution [38][39]. It has 11-size of bins with near the same logarithm interval for particles of $0.15-35 \mu \mathrm{m}$ in radius [23][24]. The model has a temporally varying emission reduction factors derived statistically using a normalized difference vegetation index (NDVI) in the different surface soil types in the Asian dust source region. The detailed description is given in [38].

\section{2) $C M A Q$ model}

The Environmental Protection Agency (EPA) Community Multiscale Air Quality (CMAQ) modeling system (http://www.cmaq-model.org) is a three-dimensional eulerian atmospheric chemistry and transport modeling system that simulates airborne pollutants, ozone concentration, particulate matters, visibility, and acidic and nutrient pollutant species throughout the troposphere [40].

The aerosol component of the CMAQ model has the particle size distribution as the superposition of three lognomal subdistributions, called modes. Fine particles with diameters less than $2.5 \mu \mathrm{m}\left(\mathrm{PM}_{2.5}\right)$ are represented by two subdistributions called the Aitken and accumulation modes. (a) $\mathrm{SO}_{2}(\mathrm{kt} / \mathrm{year} /$ grid $)$

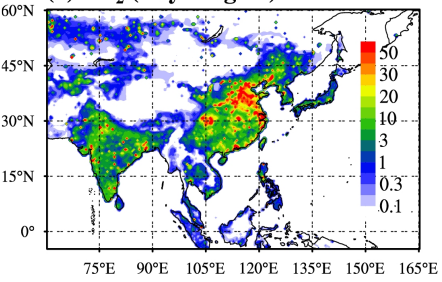

(c) $\mathrm{NH}_{3}(\mathrm{kt} /$ year/grid)

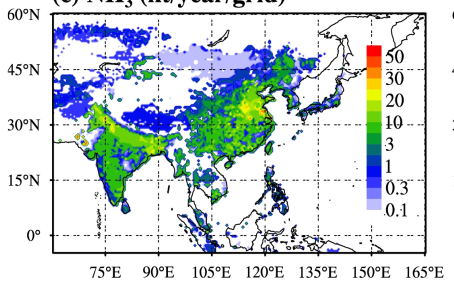

(b) $\mathrm{NO}_{\mathrm{x}}(\mathrm{kt} / \mathrm{year} / \mathrm{grid})$

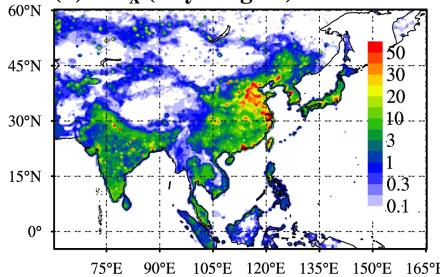
(d) $\mathbf{P M}_{10}$ (kt/year/grid)

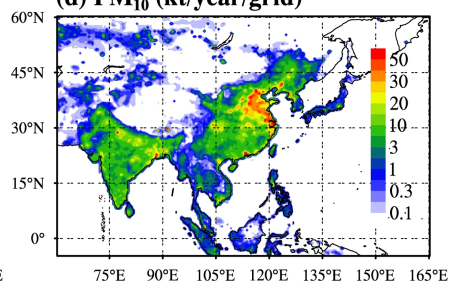

Fig. 2. Horizontal distributions of emission rate $\left(\mathrm{kt} \mathrm{yr}^{-1} \operatorname{grid}^{-1}\right)$ of (a) $\mathrm{SO}_{2}$, (b) $\mathrm{NO}_{\mathrm{X}}$, (c) $\mathrm{NH}_{3}$ and (d) $\mathrm{PM}_{10}$ in the year 2010 over Asian region (grid: $0.5^{\circ} \times\left(0.5^{\circ}\right)$ 
The Aitken mode includes particles with diameters up to approximately $0.1 \mu \mathrm{m}$ for the mass distribution and the accumulation mode covers the mass distribution in the range from 0.1 to $2.5 \mu \mathrm{m}$. The coarse mode covers the mass distribution in the range from 2.5 to $10 \mu \mathrm{m}$. The model includes the processes of coagulation, particle growth by the addition of mass and new particle formation [41].

\section{3) Emission data}

Air pollutant emission data (Fig. 2) in the year 2010 are Analysis (IIASA; ftp://www.iiasa.ac.at/outgoing/may/KRF) in a grid of $0.5^{\circ}$ long. $\times 0.5^{\circ}$ lat. in the global domain. The emission data include $\mathrm{SO}_{2}, \mathrm{NO}_{\mathrm{X}}, \mathrm{NH}_{3}, \mathrm{CO}, \mathrm{VOC}, \mathrm{PM}_{10}, \mathrm{BC}$ and OC. The estimated total Asian (China's) anthropogenic emissions in the year 2010 are $48.4 \mathrm{Tg}(30.0 \mathrm{Tg}) \mathrm{SO}_{2}, 36.7 \mathrm{Tg}$ $(14.0 \mathrm{Tg}) \mathrm{NO}_{\mathrm{X}}, 43.5 \mathrm{Tg}(22.4 \mathrm{Tg}) \mathrm{VOC}, 279.0 \mathrm{Tg}(144.5 \mathrm{Tg})$ $\mathrm{CO}$, and $36.5 \mathrm{Tg}(23.0 \mathrm{Tg}) \mathrm{PM}_{10}$, suggesting more than $50 \%$ of the total anthropogenic emissions being contributed by China in the Asian domain.

Air pollutant emissions in South Korea in the year 2007 are obtained from the Clean Air Policy Supporting System (CAPSS, Korean Ministry of Environment) in a grid of $1 \times 1$ $\mathrm{km}^{2}$. The estimated total anthropogenic emission in the year 2007 are 402,525 t $\mathrm{SO}_{\mathrm{X}}, 1,187,923 \mathrm{t} \mathrm{NO}_{\mathrm{X}}, 874,699 \mathrm{t} \mathrm{VOC}$,

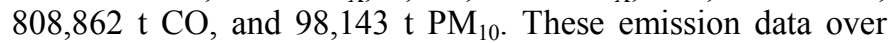
South Korea are used for the model simulation rather than using the emission inventory data of IIASA.

\section{SYNOPTIC SITUATIONS OF THE CHOSEN HAZE EVENTS}

Figure 3 shows the surface weather analysis map obtained from Korea Meteorological Administration (KMA, 2013) during the haze event period in East Asia.

The most parts of eastern China are under the influence of a surface high pressure system centered at central northern China

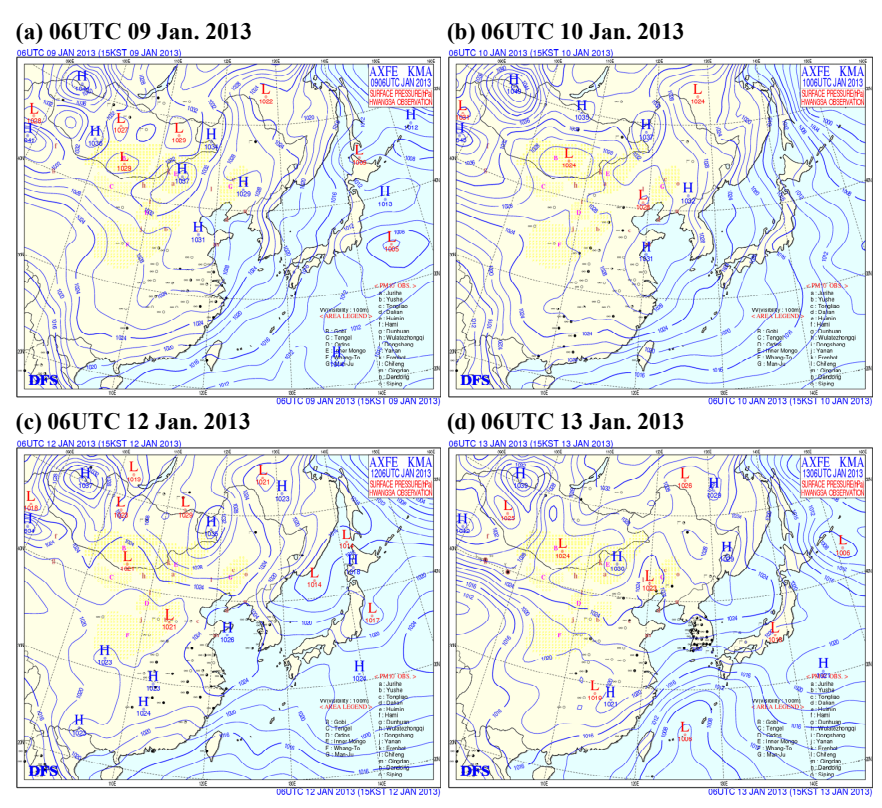

Fig. 3. Surface weather analysis maps at (a) 06 UTC 9, (b) 06 UTC 10, (c) 06 UTC 12 and (d) 06 UTC 13 January 2013. The haze is indicated by “ $\infty$ " $\left(110^{\circ} \mathrm{E}\right.$ and $\left.40^{\circ} \mathrm{N}\right)$ at 00 UTC 9 January 2013. As this high pressure system moves slowly southeastward, haze is reported in the wide region of eastern China at 06 UTC 9 January (Fig. 3a). Thereafter this surface high pressure system continuously moves further southeastward to locate in the coastal region of Shandong province at 06 UTC 10 January (Fig. 3b), the dense haze covers almost all over eastern China from northeast China to the South China Sea. At 06 UTC 12 January the surface pressure center located at Shandong province slightly moves northeastward over the Yellow Sea accompanied with further northeastward extension of the dense haze zone over South Korea (Fig. 3c).

Thereafter the dense haze occurrence zone is prevailed over South Korea and extended over Japan with the surface high pressure system is keeping to move northeastward over northeastern China (Fig. 3d). This trend is continued until 18 UTC 15 January when the surface low pressure system developed over the East China Sea moves northeastward to the East Sea of Korea. This prolonged dense haze event has caused for the Environmental Protection Bureau of China to take emergency measures in several provinces in eastern China.

\section{RESULTS OF THE MODEL SIMULATION}

\section{A. Comparison of observed and simulated aerosol $\left(P M_{10}\right)$ concentrations over South Korea}

The Aerosol Modeling System (AMS) has been employed to simulated concentrations of $\mathrm{PM}_{10}$ and pollutants for the period from 4 to 16 January 2013 that includes the dense haze event period in East Asia in the domain given in Fig. 1.

The time series of observed $\mathrm{PM}_{10}$ concentrations at several monitoring sites over South Korea (Fig. 1) are compared with the model simulated ones to see the performance of the model.

Figure 4 shows time series of hourly mean surface $\mathrm{PM}_{10}$ concentrations observed and simulated by the model at several

monitoring sites over South Korea (Fig. 1). The simulated $\mathrm{PM}_{10}$ concentrations are composed of all kinds of aerosols including Water (water droplet that is formed through the chemical reaction and hygroscopic processes), Other (sea salt and secondary organic aerosols), Asian dust (aerosols emitted from soil erosion), SIA (secondary inorganic aerosols; $\mathrm{SO}_{4}{ }^{2-}$, $\mathrm{NO}_{3}^{-}, \mathrm{NH}_{4}^{+}$), $\mathrm{BC}$ (black carbon) and $\mathrm{OC}$ (organic carbon), and unspecified $\mathrm{PM}_{10}$ (emitted anthropogenic aerosol not include above categories).

The model simulates quite well observed high $\mathrm{PM}_{10}$ concentration events that caused dense haze events over Korea. Two high aerosol-concentration events are simulated (Fig. 4). Some quantitative statistical performance measures for evaluating the model are given in Table 1 . These values reflect averages over time from 00 LST 9 to 00 LST 16 January 2013 at each monitoring site over Korea. All the statistics (Table 1) indicate a good overall agreement between observations and model results, especially at the Heuksando site with an absolute normalized bias (ANB) of $-4 \%$, an correlation coefficient (CORR) of $90 \%$ and the index of agreements (IOA) of $92 \%$.

The first event occurs at 00:00 LST (=UTC+9) 12 January at Baengnyeongdo (Fig. 1) with the surface maximum $\mathrm{PM}_{10}$ 

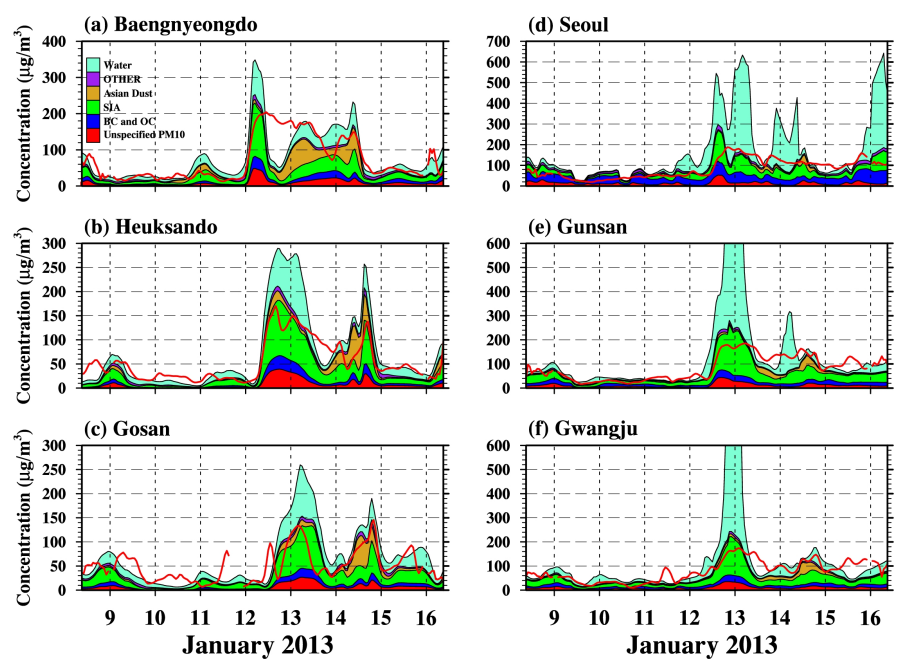

Fig. 4. Time series of hourly mean observed (red line) and modeled (various color shaded line) PM10 concentration $\left(\mu \mathrm{g} \mathrm{m}^{-3}\right)$ at (a) Baengnyeongdo, (b) Heuksando, (c) Gosan, (d) Seoul, (e) Gunsan and (f) Gwangju in Korea for the period of 09:00 LST 8 to 09:00 LST 16 January 2013

concentration more than $230 \mu \mathrm{g} \mathrm{m}^{-3}$ at 05:00 LST (Fig. 4a). This event moves southeastward to the Gosan site in Jeju island of Korea (Fig. 1) at 16:00 LST 12 January 2013 with the maximum $\mathrm{PM}_{10}$ concentration of $150 \mu \mathrm{g} \mathrm{m}^{-3}$ at 05:00 LST 13 January (Fig. 4c). While at the inland site of Gwangju that is located about $500 \mathrm{~km}$ to the southeast of Baengnyeongdo (Fig. 1) the event occurs at 09:00 LST 12 January with the simulated maximum $\mathrm{PM}_{10}$ concentration exceeding $200 \mu \mathrm{g} \mathrm{m}^{-3}$ at 00:00 LST 13 January (Fig. 4f). The observed and simulated high aerosol concentrations of the first event are mainly contributed by the anthropogenic aerosols (Fig. 4). Among these aerosols the secondary inorganic aerosols $\left(\mathrm{SO}_{4}{ }^{2-}, \mathrm{NO}_{3}^{-}\right.$, and $\left.\mathrm{NH}_{4}{ }^{+}\right)$are predominated, suggesting the importance of converted aerosols from emitted air pollutants.

The second high aerosol concentration event occurs at 16:00 LST 12 January at the Baengnyeongdo site with the maximum surface $\mathrm{PM}_{10}$ concentration of more than $150 \mu \mathrm{g} \mathrm{m}^{-3}$ at 10:00 LST 13 January and ends at around 15:00 LST 14 January 2013 (Fig. 4a). This event moves slowly southeastward to Gosan (starting time at 00 LST 14 and ending time at 00 LST 15), with maximum surface $\mathrm{PM}_{10}$ concentration of $150 \mu \mathrm{g}$ $\mathrm{m}^{-3}$ (Fig.5c) and to Gwangju (starting time at 06:00 LST 14 and ending time at 16:00 LST 15 January) with the maximum surface $\mathrm{PM}_{10}$ concentration of about $150 \mu \mathrm{g} \mathrm{m} \mathrm{m}^{-3}$ (Fig. 4f). During the second event period hazes are reported all over South Korea (Figs. 3c and d), suggesting the haze event
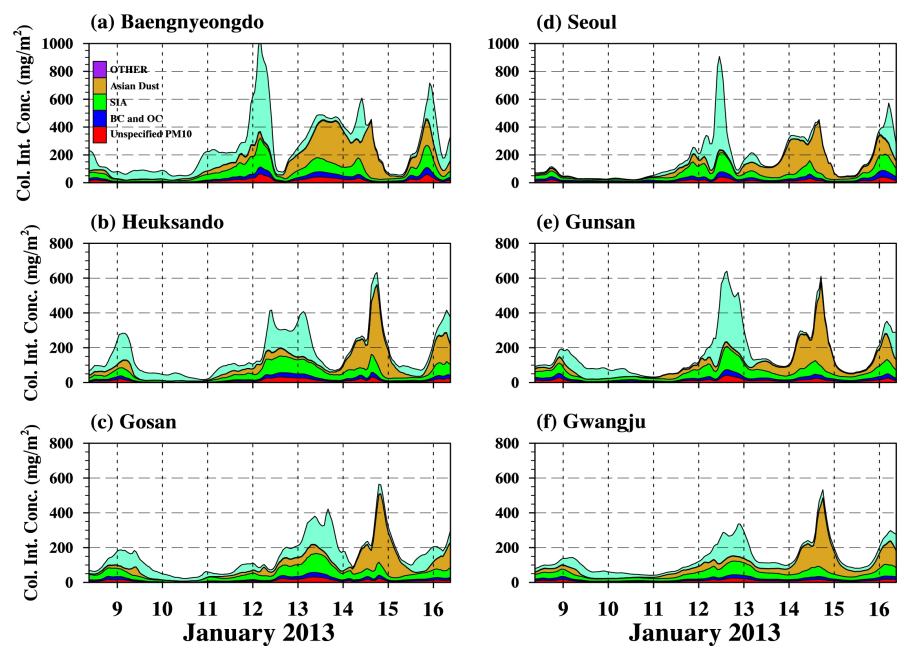

(f) Gwangju

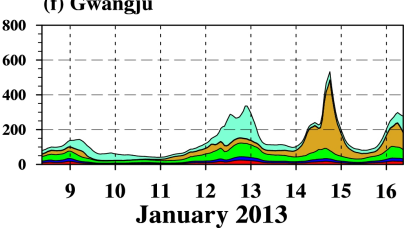

Fig. 5. The same as in Fig. 4 except for the column integrated $\mathrm{PM}_{10}$ concentration $\left(\mathrm{mg} \mathrm{m}^{-2}\right)$

reported in South Korea being caused by the high aerosol concentration.

The second high aerosol-concentration event in Figure 4 is contributed by the mixture of Asian dust aerosol and the anthropogenic aerosols that is different from the first event which is mainly caused by the anthropogenic aerosol. The difference between the first and second high aerosolconcentration events is more clearly seen in Figure 5. The column integrated $\mathrm{PM}_{10}$ concentration (Fig. 5) indicates that the first high aerosol-concentration event is mainly contributed by anthropogenic aerosols, especially by secondary inorganic aerosols (SIA) originated from air pollutants, whereas the second event is largely contributed by the Asian dust aerosol originated from the Asian dust source region at all monitoring sites in Korea (Figs. 5a, b, c, d, e, and f). Note that the upper level long-range transported Asian dust aerosol is largely attributed to the haze phenomena of the second event; the column integrated concentration of the Asian dust aerosol is much greater than that of the anthropogenic aerosols for the second event (Fig. 5) whereas that of the anthropogenic aerosol is predominated for the first event (Fig. 5).

The surface weather analysis map in Fig. 3c clearly indicates that the first high aerosol concentration is related with the haze reports over the western parts of the Korean peninsula. It is worthwhile to note that the observed $\mathrm{PM}_{10}$ concentration in Figure 4 does not include the water droplet aerosol since the sampled air is desiccated before measuring $\mathrm{PM}_{10}$ concentration. Therefore, the comparison between the measured and simulated $\mathrm{PM}_{10}$ concentrations should be made without water

TABLE I. PERFORMANCE STATISTICS OF AMS FOR THE AEROSOL CONCENTRATION (PM P $\left._{10}\right)$

\begin{tabular}{|c|c|c|c|c|c|c|c|c|c|}
\hline \multirow{2}{*}{ Site } & \multicolumn{9}{|c|}{ Parameter } \\
\hline & Total \# & Mean Obs. $\left(\mu g \mathrm{~m}^{-3}\right)$ & Mean Mod. $\left(\mu g \mathrm{~m}^{-3}\right)$ & STD. Obs. & STD. Mod. & $A N B^{a}(\%)$ & $\operatorname{CORR}^{b}$ & $F A C 2^{c}$ & $I O A^{d}$ \\
\hline Baengnyeongdo & 165 & 75.1 & 60.9 & 63.0 & 54.9 & -19 & 0.78 & 0.89 & 0.86 \\
\hline Heuksando & 165 & 56.5 & 54.5 & 43.3 & 60.4 & -4 & 0.90 & 0.62 & 0.92 \\
\hline Gosan & 158 & 51.9 & 48.2 & 34.1 & 44.6 & -7 & 0.72 & 0.58 & 0.83 \\
\hline Seoul & 165 & 84.8 & 87.6 & 47.9 & 48.6 & 3 & 0.66 & 0.85 & 0.80 \\
\hline Gunsan & 165 & 83.5 & 73.6 & 54.1 & 64.4 & -12 & 0.81 & 0.93 & 0.89 \\
\hline Gwangju & 165 & 79.0 & 63.4 & 45.1 & 50.8 & -20 & 0.75 & 0.78 & 0.83 \\
\hline
\end{tabular}



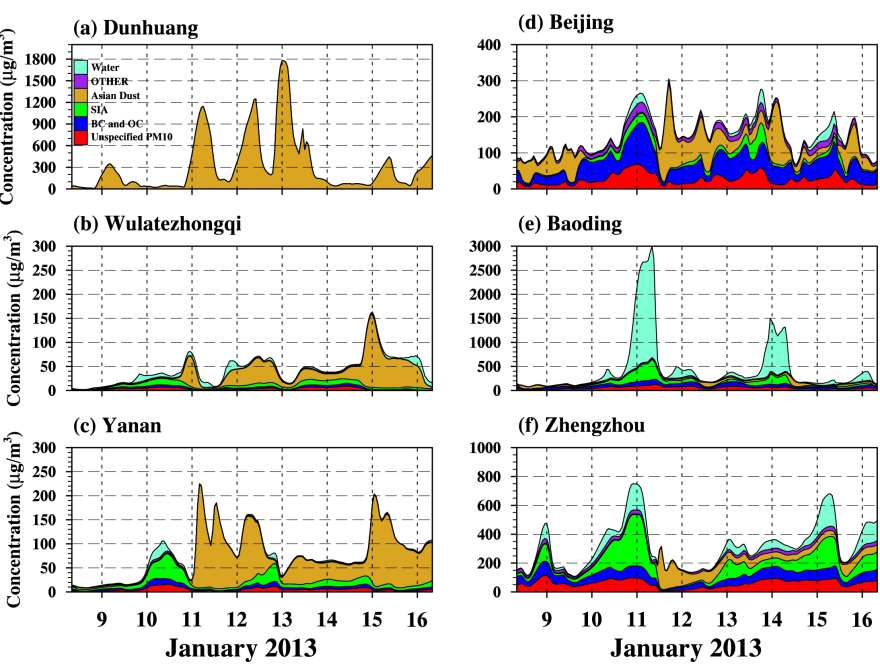

(e) Baoding

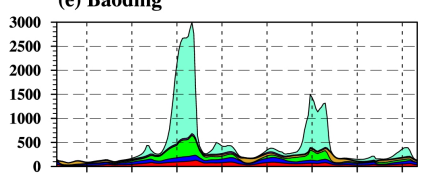

(f) Zhengzhou

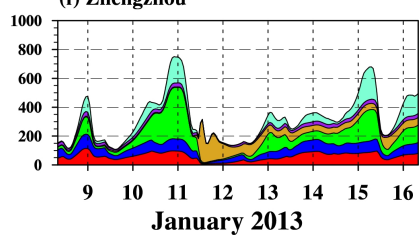

Fig. 6. The same as in Fig. 4 except for the model simulated $\mathbf{P M}_{10}$ concentration $\left(\mu \mathrm{g} \mathrm{m}^{-3}\right)$ at (a) Dunhuang, (b) Wulatezhongqi and (c) Yanan located in the Asian dust source region, and at (d) Beijing, (e) Baoding and (f) Zhengzhou located near the eastern border of the Asian dust source region.

droplet aerosols in the simulated $\mathrm{PM}_{10}$ concentration. However, the water droplet aerosol concentration is very important to distinguish the hygroscopic aerosol from non-hygroscopic aerosol and the mist from haze. It also affects the visibility significantly [21].

\section{B. Temporal variations of model simulated $P M_{10}$ concentration in China and Japan}

Figure 6 shows time series of hourly mean surface $\mathrm{PM}_{10}$ concentration at three sites in the Asian dust source region (Fig. 1 and Figs. 6a-c) and three sites at the eastern border of the Asian dust source region in China (Fig. 1 and Figs. 6d-f). Asian dust occurs every day during the analysis period starting from 00 LST (UTC+8) 11 January with varying intensity depending on the site and time (Figs. 6a-c). The maximum hourly mean $\mathrm{PM}_{10}$ concentration of $1,800 \mu \mathrm{g} \mathrm{m}^{-3}, 150 \mu \mathrm{g} \mathrm{m}^{-3}, 200 \mu \mathrm{g}, \mathrm{m}^{-3}$, respectively occurs at 00 LST 13 at the Dunhung site (Fig. 6a), 00 LST 15 at the Wulantezhongi site (Fig. 6b) and 04 LST 11 January at the Yanan site (Fig. 6c). Most of aerosols at these sites are contributed by the Asian dust aerosol (Figs. 6a-c).

However, toward the border of the Asian dust source region, the contribution of anthropogenic aerosols becomes more important as seen in Figs. 6d-f. The high anthropogenic aerosol concentration of more than $250 \mu \mathrm{g} \mathrm{m}^{-3}$ at Beijing (Fig. 6d), and more than $400 \mu \mathrm{g} \mathrm{m}^{-3}$ at Baoding (Fig. 6e) and Zhengzhou (Fig. 6f) throughout the analysis period together with the high water droplet aerosol concentration has caused dense haze events reported in Fig. 3. The most predominant aerosol for this haze event is the secondary inorganic aerosols that are formed by gas-to-particle conversion processes in the atmosphere, suggesting the importance of $\mathrm{SO}_{2}, \mathrm{NO}_{\mathrm{X}}$ and $\mathrm{NH}_{3}$ emissions.

Figure 7 shows the time series of model simulated hourly mean $\mathrm{PM}_{10}$ concentration at three sites in the central eastern low land in China (Figs. 7a-c) where pollutants emissions are high (Fig. 2), and the three eastern coastal sites in China (Figs.
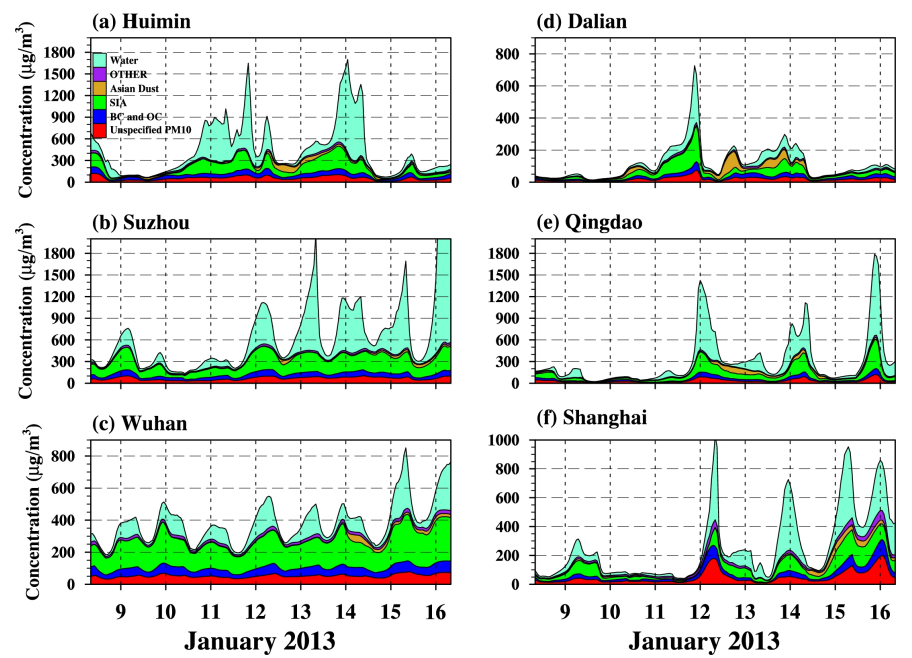

(f) Shanghai

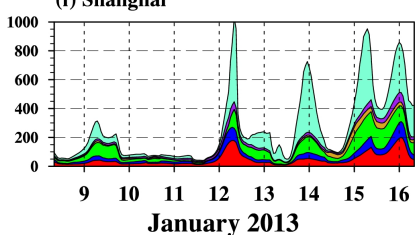

Fig. 7. The same as n Fig. 6 Except at (a) Huimin, (b) Suzhou and (c) Wuhan located in the eastern low flat region, and (d) Dalian, (e) Qingdao and (f) Shanghai located in the eastern coastal region of China.

7d-f). More than $300 \mu \mathrm{g} \mathrm{m}^{-3}$ of $\mathrm{PM}_{10}$ concentration occurs during the period from 10 to late 14 January at the site located in the northern low land region (Fig. 7a) while at the other sites located in the low land (Figs $8 \mathrm{~b}$ and c) the surface $\mathrm{PM}_{10}$ concentration increases throughout the analysis period with the maximum $\mathrm{PM}_{10}$ concentration of more than $500 \mu \mathrm{g} \mathrm{m} \mathrm{m}^{-3}$. Aerosols are mainly composed of anthropogenic aerosols including SIA, $\mathrm{BC}, \mathrm{OC}$ and unspecified $\mathrm{PM}_{10}$ that are originated from the pollutant emissions. The high concentrations of anthropogenic aerosols (especially the secondary inorganic aerosol) together with that of the water droplet aerosol have caused the prolonged haze event in this region of China (Fig. 3).

At the Dalian site (Fig. 7d) located in the northeastern coast of China (Fig. 1), two main heavy aerosol events occur for the periods of 06 LST 10 to 00 LST 12 January and 09 LST 12 to 09 LST 14 January. The first one is mainly contributed by

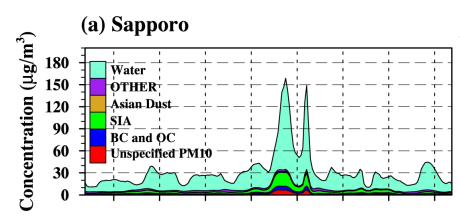
(d) Sapporo
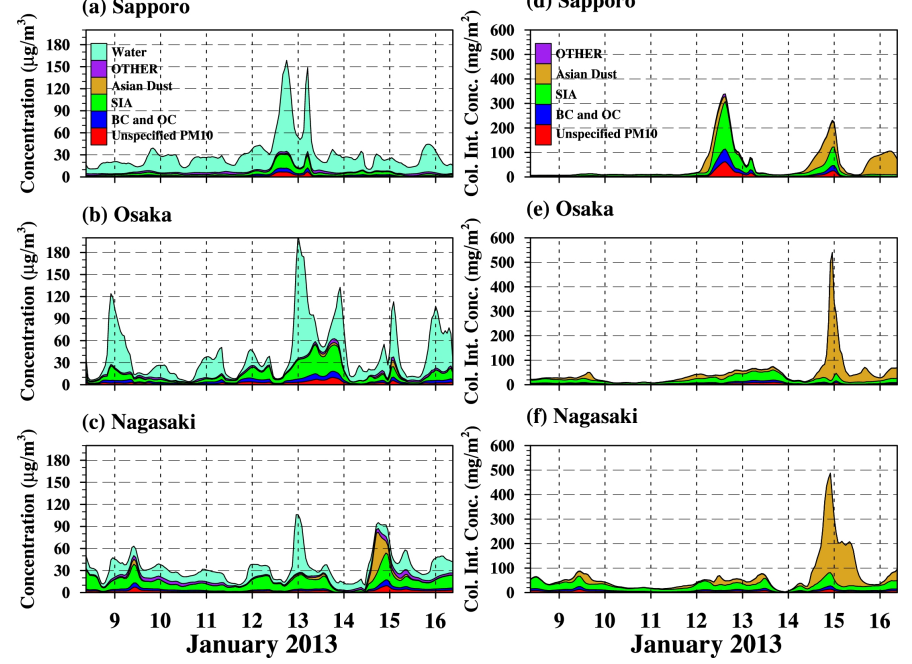

Fig. 8. Time series of model simulated surface $\mathrm{PM}_{10}$ concentration $\left(\mu \mathrm{g} \mathrm{m}^{-3}\right)$ at (a) Sapporo, (b) Osaka and (c) Nagasaki and the column integrated $\mathrm{PM}_{10}$ concentration $\left(\mathrm{mg} \mathrm{m}^{-2}\right)$ at (d) Sapporo, (e) Osaka and (f) Nagasaki. 
(a) Surface mean PM10 concentration

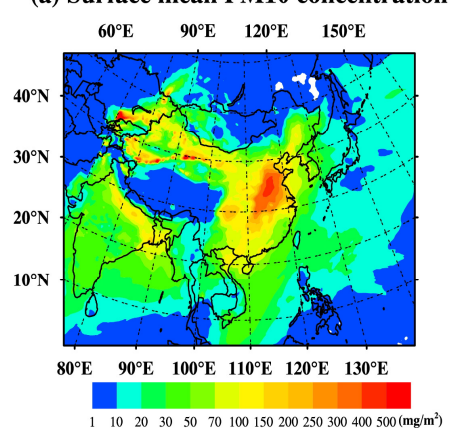

(b) Surface mean anth. aerosol conc.

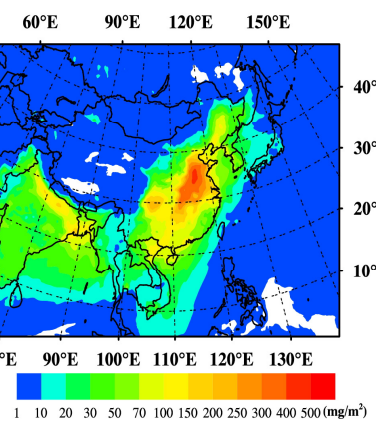

Fig. 9. Horizontal distributions of surface mean (a) $\mathrm{PM}_{10}$ concentration ( $\mu \mathrm{g} \mathrm{m}$ ${ }^{3}$ ) and (b) anthropogenic aerosol concentration $\left(\mu \mathrm{g} \mathrm{m}^{-3}\right)$ averaged for the period from 00 UTC 10 to 00 UTC 16 January 2013.

anthropogenic aerosols with the maximum surface $\mathrm{PM}_{10}$ concentration of more than $300 \mu \mathrm{g} \mathrm{m}^{-3}$ at 23 LST 11 January, while the second one is contributed by the mixture of anthropogenic aerosols and the Asian dust aerosol originated from northern China.

At the coastal sites of Qingdao and Shanghai (Figs. 7e and f) the high aerosol concentration event has occurred before 00 LST 10 January as is the case at sites in the high pollutants emission region (Figs. 7a, b and c) but the main event starts to occur from 14 LST 11 January with increasing intensity throughout the analysis period (Figs. 7e and $\mathrm{f}$ ). The maximum surface $\mathrm{PM}_{10}$ concentration is more than $600 \mu \mathrm{g} \mathrm{m}^{-3}$ at $22 \mathrm{LST}$ 15 at Qingdao and $420 \mu \mathrm{g} \mathrm{m}^{-3}$ at $00 \mathrm{LST} 16$ January at Shanghai causing dense haze events in these regions. Aerosols are mainly composed of anthropogenic aerosols for the first event occurred at 00 LST 12 and the third event at 22 LST 15 January at the Qingdao site (Fig. 7e) whereas the second event occurred at 10 LST 14 January is composed of the mixture of anthropogenic aerosols and Asian dust aerosol transported from northern China in the dust source region. Although the concentrations of Asian dust aerosol for the second event are small compared with that of anthropogenic aerosols at the surface level (Fig. 7), the column integrated $\mathrm{PM}_{10}$ concentration (not shown) shows that the Asian dust aerosol is predominated for the second event, suggesting the upper level long-range transported Asian dust aerosol being main cause of the dense haze event at Qingdao.

However, the contribution of Asian dust aerosol to the total $\mathrm{PM}_{10}$ concentration is rather small but that of the locally emitted $\mathrm{PM}_{10}$ concentration is rather large at Shanghai throughout the whole analysis period (Fig. 7f).

The high aerosol concentration events occurred in China (Figs. 6 and 8) have been transported to Japan with diminished intensity. At the Sapporo site in northern Japan the first anthropogenic aerosol event occurs from 00 LST (=UTC+9) 12 to 09 LST 13 January (Figs. 8a and d) and then the second mixed aerosol event (anthropogenic and Asian dust aerosols) occurs from 09 LST 14 to 04 LST 15 January with low PM 10 concentration at the surface (Figs. $8 \mathrm{a}$ and d).

A similar feature can be seen at the Osaka site (Figs. 8b and e) located in central Japan and the Nagasaki site (Figs. 8c and f) in Southern Japan with delayed occurrence time by about 12

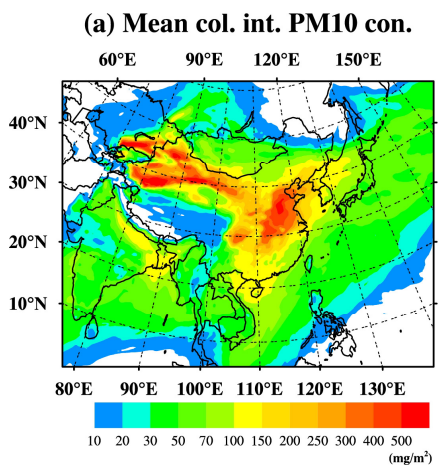

(b) Mean col. int. anth. aerosol con.

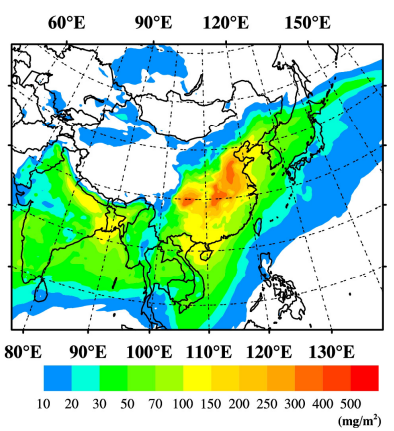

Fig. 10. Horizontal distributions of column integrated mean (a) $\mathrm{PM}_{10}$ concentration $\left(\mathrm{mg} \mathrm{m}^{-2}\right)$ and (b) anthropogenic aerosol concentration $\left(\mathrm{mg} \mathrm{m}^{-2}\right)$ averaged for the period from 00 UTC 10 to 00 UTC 16 January 2013.

hours for the first anthropogenic aerosol event. However, the second mixed aerosol event (more dominated by Asian dust aerosol in Figs. 8d, e and f) occurs almost the same time of 00 LST 15 January at all 3 sites, suggesting the upper level longrange transported Asian dust aerosol arrived over Japan almost the same time.

\section{HORIZONTAL DISTRIBUTIONS OF MEAN} CONCENTRATIONS FOR THE PERIOD FROM 00 UTC 10 TO 00 UTC 16 JANUARY 2013

\section{A. The horizontal distribution of mean aerosol ( $\left.P M_{10}\right)$ concentration}

Figure 9a shows surface mean total aerosol concentration $\left(\mathrm{PM}_{10}\right)$ averaged for the period from 00 UTC 10 to 00 UTC 16 January 2013. The aerosols originated in Asia affect all Asian regions including the Asian continent, the northwestern Pacific Ocean, the South China Sea and the Bay of Bengal. The high aerosol concentration exceeding $100 \mu \mathrm{g} \mathrm{m}^{-3}$ covers over eastern China, the north of the Tibetan Plateau and northern India (Fig. 9a). Those high aerosol concentrations over eastern China and northeastern India are mainly contributed by the anthropogenic aerosols (Fig. 9b) produced from high pollutants emissions (Fig. 2), and have caused the dense haze events in these regions (Fig. 3). Whereas the high aerosol concentrations over northwestern China to the north of the Tibetan Plateau are mostly contributed by Asian dust aerosol emitted in the Asian dust source region (compare Figs. 9a and b).

Figure 10 shows mean atmospheric aerosol loadings (column integrated aerosol $\left(\mathrm{PM}_{10}\right)$ concentration) averaged for the period from 00 UTC 10 to 00UTC 16 January 2013. Aerosols produced in the Asia continent affect all over analysis domain (Fig. 10a) except in the southeastern corner of the model domain over the subtropical high pressure zone.

The high atmospheric aerosol loading zone exceeding $100 \mathrm{mg}$ $\mathrm{m}^{-2}$ extends southeastward from the Taklamakan desert area of the Asian dust source region to eastern China where it merges with another high aerosol loading zone extending northeastward from the South China Sea through the Korean peninsula to the East Sea of Korea. The high aerosol loading of more than $100 \mathrm{mg} \mathrm{m}^{-2}$ over northwestern China to the north of the Tibetan plateau is mainly attributed to Asian dust aerosol 
(a) Total deposition of PM10 concentration

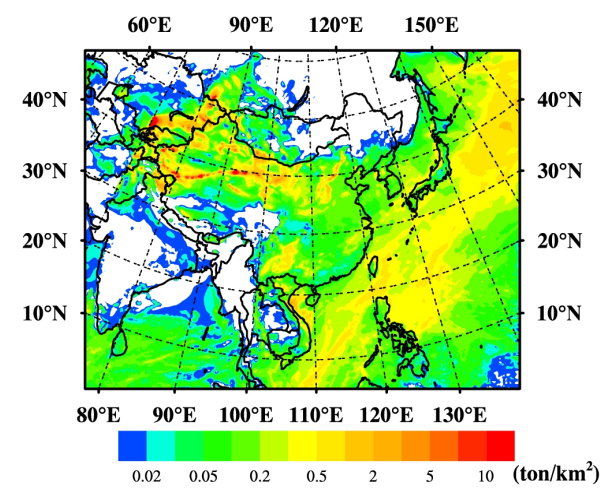

(b) Total dry deposition of PM10 concentration

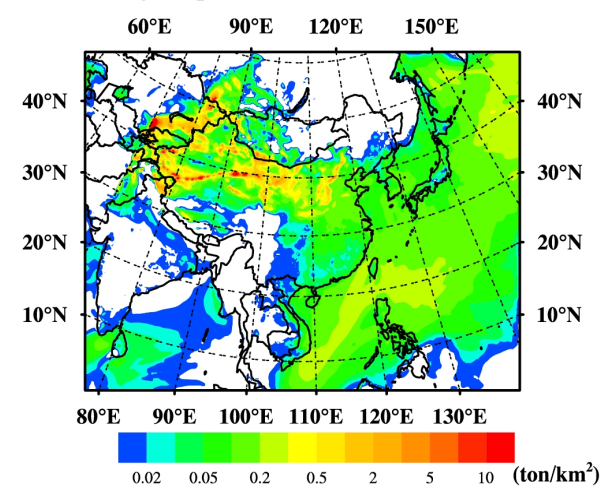

(c) Total wet deposition of PM10 concentration

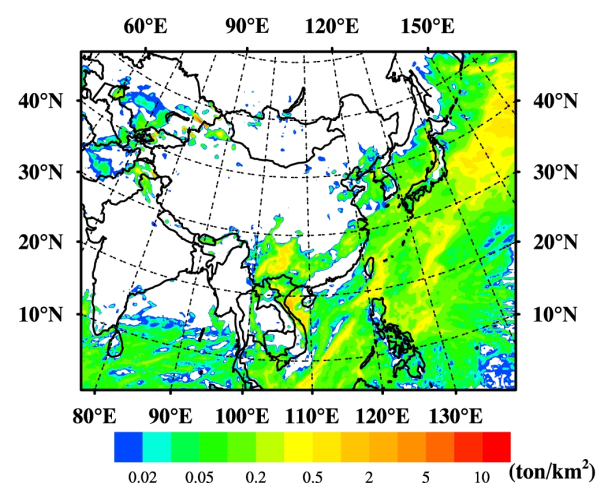

Fig. 11. Horizontal distributions of (a) total deposition (wet+dry) of $\mathrm{PM}_{10}(\mathrm{t}$ $\left.\mathrm{km}^{-2}\right)$, (b) total dry deposition of $\mathrm{PM}_{10}\left(\mathrm{t} \mathrm{km}^{-2}\right)$ and (c) total wet deposition of $\mathrm{PM}_{10}\left(\mathrm{t} \mathrm{km}^{-2}\right)$ for the period from 00 UTC 10 to 00 UTC 16 January 2013.

while those over eastern China and Northern India are composed of the anthropogenic aerosols (Figs. 10a and b).

It is worthwhile to note that $100 \mathrm{mg} \mathrm{m}^{-2}$ isoline of the column integrated mean anthropogenic aerosols concentration (Fig. 10b) extends up to the northern part of the Yellow Sea but that of the total aerosol concentration (Fig. 10a) extends further downwind to the East Sea through the Yellow Sea and the Korean peninsula, suggesting a significant amount of Asian dust aerosol being contributed to the total aerosol concentration over the Yellow Sea, the Korean peninsula and the East Sea.

\section{HORIZONTAL DISTRIBUTION OF TOTAL AEROSOL DEPOSITION FOR THE PERIOD FROM 00 UTC 10 TO 00 UTC 16 JANUARY 2013}

The deposition of aerosols affects significantly marine and terrestrial ecosystems. Figure 11a shows the total deposition (wet+dry) of anthropogenic and Asian dust aerosols for the period of the haze event in eastern Asia from 00 UTC 10 to 00 UTC 16 January 2013. The total aerosol deposition of more the $300 \mathrm{~kg} \mathrm{~km}{ }^{-2}$ occurs most of Asian dust source region to the north of the Tibetan plateau, Yunnan province, the Beibu gulf, the western coast of Japan, a wide region extending southwestward from the Northwestern Pacific Ocean to Philippines (Fig. 11a). Most of high aerosol deposition to the north of the Tibetan plateau in the Asian dust source region is largely contributed by the dry deposition (Fig. 11b) whereas all other high aerosol deposition regions including Yunnan province, the Beibu gulf, the western coast of Japan and over oceans (the Northwestern Pacific Ocean, the South China Sea) are mainly contributed by wet deposition (Fig. 11c). The large amount of aerosol input more than $1000 \mathrm{~kg} \mathrm{~km}^{-2}$ to the Seas from the Northwestern Pacific Ocean, through the East China Sea to the South China Sea, could affect significantly marine ecology in this region (Fig. 11a).

The present analysis indicates that the high Asian dust emission in northern China and Mongolia and high pollutant emissions in China could produce severe environmental problems including dense haze and mist events that cause severe visibility reduction and adverse impacts on human health through the increased atmospheric aerosol loadings and on terrestrial and marine ecologies through the excess deposition of aerosols.

\section{CONCLUSIONS}

The Aerosol Modeling System (AMS) based on the ADAM2 model for the Asian dust aerosol and the CMAQ model for the anthropogenic aerosols has been employed to simulate air quality in Asia in association with dense haze events observed in East Asia for the period from 10 to 15 January 2013. These events caused for the Environmental Protection Bureau in Beijing, China to take emergency measures. The simulated aerosols $\left(\mathrm{PM}_{10}\right.$; Asian dust aerosols and anthropogenic aerosols) concentrations have been compared with the monitored $\mathrm{PM}_{10}$ concentrations at several sites scattered over South Korea to ensure the usefulness of the model for the further analysis of air quality in Asia.

It is found that the AMS model can simulate quite reasonably the observed $\mathrm{PM}_{10}$ concentrations during the period of the dense haze events that have caused severe air pollution problems in China and the downwind region of Korea, and that can identify the contribution of each type of aerosols to these poor air quality events.

It is also found that the dense haze events associated with high aerosol concentration events observed in Korea are caused by two different transport processes; the one is mainly affected by the anthropogenic aerosols originated from the pollutants emitted in eastern China while the other is affected by a mixture of the Asian dust aerosol from northern China in the Asian dust source region and the anthropogenic aerosols from 
coastal eastern China of the high pollutant emission region. The anthropogenic aerosols during the events period are found to be primarily contributed by the secondary inorganic aerosols, suggesting the importance of the emission of aerosol precursors including $\mathrm{SO}_{2}, \mathrm{NO}_{\mathrm{X}}$ and $\mathrm{NH}_{3}$.

The atmospheric aerosol loadings and the total deposition of aerosols in association with these events clearly indicate that not only the air quality in the whole East Asia regions but the marine and terrestrial eco-systems could be significantly affected by these events.

In view of the increasing occurrence trend of such events in East Asia, some reduction measures of pollutants emissions, especially in China are required for keeping sustainable environment in East Asia.

This study mainly pertains to a dense haze event case to understand the impact of the each type of aerosols on this event but further studies for a year-long period are required to assess the impact of pollutants emissions on environment and ecosystems in the Asia region.

\section{ACKNOWLEDGMENT}

This work was funded by the Korea Meteorological Administration Research and Development Program under grant NIMR2013.

\section{REFERENCES}

[1] T.M. Johnson, F. Liu, and R. Newfarmer, "Clear water, blue skies." Clear water, blue skies 1.2, 1997, pp. 1-129.

[2] S. Rodriguez, X. Querol, A. Alastuey, G. Kallos, and O. Kakaliagou, "Saharan dust contributions to PM10 and TSP levels in Southern and Eastern Spain," Atmos. Environ., vol. 35(14), pp. 2433-2447, 2001.

[3] X. Querol, J. Pey, M. Pandolfi, A. Alastuey, M. Cusack, N. Pérez, ... and S. Kleanthous, "African dust contributions to mean ambient $\mathrm{PM}_{10}$ masslevels across the Mediterranean Basin," Atmos. Environ., vol. 43(28), pp. 4266-4277, 2009.

[4] J.M. Prospero, I. Olmez, and M. Ames, " $\mathrm{Al}$ and $\mathrm{Fe}$ in $\mathrm{PM}_{2.5}$ and $\mathrm{PM}_{10}$ suspended in South-Central Florida: The impact of long range transport of African mineral dust," Water, Air, and Soil Pollution, vol. 125, pp. 291-317, 2001.

[5] G. Cowie, W. Lawson, and N. Kim, "Australian dust causing respiratory disease admissions in some North Island, New Zealand Hospitals," New Zeal. Med. J., vol. 123(1311), p. 87, 2010.

[6] D.V. Bates, B.R. Fish, T.F. Hatch, T.T. Mercer, and P.E. Morrow, "Deposition and retention models for internal dosimetry of the human respiratory trac," Health Phys., vol. 12, pp. 173-207, 1966.

[7] D.W. Dockery, J. Schwartz, and J.D. Spengler, "Air Pollution and Daily Mortality: Associations with Particulates and Acid Aerosols," Environ. Res., vol. 59, pp. 362-373, 1992.

[8] D.W. Dockery, C.A. Pope, X. Xu, J.D. Spengler, J.H. Ware, M.E. Fay, B.G. Ferris, and F.E. Speizer, "An association between air pollution and mortality in six U.S. cities,” New Engl. J. Med., vol. 329, pp. 1753-1759, 1993.

[9] F.S. Binkowski and U. Shankar, "The regional particulate matter model, 1. Model description and preliminary results," J. Geophys. Res., vol. 100(D12), pp. 26191-26209, 1995.

[10] I. Balásházy, W. Hofmann, and T. Heistracher, "Local particle deposition pattern may play a key role in the development of lung cancer,” J. Appl. Physiol., vol. 94, pp. 1719-1725, 2003.
[11] M.E. Davis, F. Laden, J.E. Hart, E. Gashick, and T.J. Smith, "Economic activity and trends in ambient air pollution," Environ. Health Persp., vol. 118, pp. 614-619, 2010.

[12] P.T.B.S. Branco, M.C.M Alvim-Ferraz, F.G. Martins, and S.I.V Sousa, "A microenvironmental modelling methodology to assess children's exposure to indoor air pollution in Porto, Portugal," Recent Advances in Environmental Science, pp. 211-216, 2013 (WSEAS).

[13] Intergovernmental Panel on Climate Change, Climate Change 1995: The science of Climate change, Cambridge University Press, 1996.

[14] M.Z. Jacobson, "Strong radiative heating due to the mixing state of black carbon in atmospheric aerosols," Nature, vol. 409(6821), pp. 695697, 2001.

[15] Y.J. Kaufman, D. Tanré, and O. Boucher, "A satellite view of aerosols in the climate system," Nature, vol. 419(6903), pp. 215-223, 2002.

[16] J.G. Watson, "Visibility: Science and regulation," J. Air Waste Ma., vol. 52, pp. 628-713, 2002.

[17] P. Crutzen, "New directions: the growing urban heat and pollution island effect - impact on chemistry and climate," Atmos. Environ., vol. 38, pp. 3539-3540, 2004.

[18] L.-S. Chang and S.-U. Park, "Direct radiative forcing due to anthropogenic aerosols in East Asia during April 2001," Atmos. Envoron., vol. 38, pp. 4467-4482, 2004.

[19] J.E.P. Penner, X. Dong, and Y. Chen, "Observational evidence of change in radiative forcing due to the indirect aerosol effect," Nature, vol. 427(6971), pp. 231-234, 2004.

[20] S.-U. Park, L.-S. Chang, and E.-H. Lee, "Direct radiative forcing due to aerosols in East Asia during a Hwangsa (Asian dust) event observed in 18-23 March 2002 in Korea," Atmos. Environ., vol. 39, pp. 2593-2606, 2005.

[21] S.-U. Park, J.H. Cho, and M.-S. Park, "Identification of visibility reducing weather phenomena due to aerosols," Environmental Management and Sustainable Development, vol. 2, pp. 126-142, 2013a.

[22] H.-J. In and S.-U. Park, "The soil particle size dependent emission parameterization for an Asian dust (Yellow Sand) observed in Korea on April 2002," Atmos. Environ., vol. 37, pp. 4625-2636, 2002.

[23] S.-U. Park and H.-J. In, "Parameterization of dust emission for the simulation of the yellow sand (Asian dust) observed in March 2002 in Korea," J. Geophys. Res.. vol. 108(D19), p. 4618, 2003.

[24] S.-U. Park and E.-H. Lee, "Parameterization of Asian dust (Hwangsa) particle-size distributions for use in dust emission model," Atmos. Environ., vol. 38, pp. 2155-2162, 2004.

[25] X. Yu, B. Zhu, Y. Yin, J. Yang, Y. Li, and X. Bu, "A comparative analysis of aerosol properties in dust and haze-fog days in a Chinese urban region," Atmos. Res., vol. 99, pp. 241-247, 2011.

[26] K.H. Lee, Y.J. Kim, and M.J. Kim, "Characteristics of aerosol observed during two severe haze events over Korea in June and October 2004," Atmos. Environ., vol. 40, pp. 5146-5155, 2006.

[27] S.-U. Park, J.H. Cho, and M.-S. Park, "A simulation of Aerosols in Asia with the use of ADAM2 and CMAQ," Advances in Fluid Mechanics and Heat \& Mass Transfer, pp. 258-263, 2012.

[28] H.Z. Che and X.Y. Zhang, "Horizontal Visibility Trends in China 19812005," Geophys. Res. Lett., vol 34, doi: 10.1029/2007GL031450, 2007.

[29] R. Gautam, N.C. Hsu, M. Kafatos, and S.C. Tsay, "Influences of winter haze on fog/low cloud over the Indo-Gangetic plains," J. Geophys. Res., vol. 112(D5), doi:10.1029/2005JD007036, 2007.

[30] K. Wang, R.E. Dickinson, and S. Liang, "Clear sky visibility has decreased over land globally from 1973 to 2007," Science, vol. 323(5920), pp. 1468-1470, 2009.

[31] B.J. Finlayson-Pitts and N.J. Pitts Jr, Atmospheric chemistry. Fundamentals and experimental techniques, Wiley, 1986.

[32] J.H. Seinfeld, Atmospheric chemistry and physics of air pollution, Wiley, 1986.

[33] P. Warneck, Chemistry of the natural atmosphere, Academic Press, 1988.

[34] S.-U. Park, "The aerosol modeling system for the simulations of high aerosol concentration events in East Asia,", Recent Advances in Environmental Science, P3 (plenary lecture in WSEAS), 2013. 
[35] S.-U. Park, J.H. Cho, and M.-S. Park, "A simulation of haze and mist events observed in east Asia during 19-22 May 2010 using the Aerosol Modeling System (AMS)," Recent Advances in Environmental Science, pp. 204-210, 2013b (WSEAS).

[36] G.A. Grell, J. Dudhia, and D.R. Stauffer, A description of 5th generation Penn State/NCAR mesoscale model (MM5), NCAR TECH., Note NCAR/TN-398, 1994.

[37] J. Dudhia, D. Grill, Y.-R. Guo, D. Hausen, K. Manning, and W. Wang, PSU/NCAR mesoscale modelling system tutorial class notes (MM5 modelling system version 2), 1998.

[38] S.-U. Park, A. Choe, E.-H. Lee, M.-S. Park, and X. Song, "The Asian dust aerosol model 2 (ADAM2) with the use of normalized difference vegetation data (NDVI) obtained from the spot4/vegetation data," Theor. Appl. Climatol., vol. 101, pp. 191-208, 2010.

[39] Y. Shao, E. Jung, and L.M. Leslie, "Numerical prediction of northeast Asian dust storms using an integrated wind erosion modeling system," J. Geophys. Res., vol. 107(D24), p. 4814, doi:10.1029/2001JD001493, 2002.

[40] University of North Carolina, Operational Guidance for the Community Multiscale Air Quality (CMAQ) Modeling System, Community Modeling and Analysis System Institute for the Environment, 2010.

[41] F.S. Binkowski and S.J. Roselle, "Models-3 Community Multiscale Air Quality (CMAQ) model aerosol component 1. Model description," J. Geophys. Res., vol. 108(D6), p. 4183, 2003.

\section{Creative Commons Attribution License 4.0 (Attribution 4.0 International, CC BY 4.0)}

This article is published under the terms of the Creative Commons Attribution License 4.0 https://creativecommons.org/licenses/by/4.0/deed.en_US 